\title{
ADVANTAGES, CHALLENGES AND WEAKNESSES \\ OF SPA TOURISM IN SERBIA
}

\author{
Goran Dašić ${ }^{1}$ \\ Ana Anufrijev² \\ Dragan Milačić3
}

DOI: https://doi.org/10.31410/tmt.2019.359

\begin{abstract}
Spa tourism services have recently reached a synergy of parameters that are bounded by commercial, traditional and therapeutic practices. Spa therapies have been present since ancient times through various forms, depending on the cultural, social and political environment they have existed in. The trend of connecting medicine and spa tourism is generally known and accepted, and as such it multiplies with the following contents: architecture, sustainable development, massage, spa and wellness, traditional and modern medicine. Serbia is rich in spas and, in recent times, has been working on revitalising spa tourism and improving its content. This chapter gives a structured overview of the current situation and shows the possible ways of further development with its advantages and difficulties, for later deeper analyses.
\end{abstract}

Keywords: health tourism, spa tourism, spa destination, challenges.

\section{INTRODUCTION}

S pa tourism in Serbia is mainly focused on domestic users. The paradox is that it is expensive $\checkmark$ for the majority of the domestic population, and again, it has not become attractive enough for foreign tourists. Serbia has an impressive spa capacity. However, the long transformation and revitalisation of this sector has influenced the culture of spa tourism. On the other hand, this sector is available to a particular population with the participation of National Health Insurance Fund. It is necessary to continuously work on the affirmation and improvement of services. Also, new measures in the near future require higher level of staff professionalism and a stronger marketing strategy of this tourist placement.

\section{THE VIEW ON THE ECONOMIC BRANCH OF TOURISM}

Tourism represents one of the most important industries in many countries today and a potential for their further development and realisation of macroeconomic policy goals. The advantages of tourism are numerous. Apart from the direct impact on the economy of a country, tourism as an economic branch has large indirect and positive side effects that are often neglected.

The direct tourism benefits include: products and services (accommodation, transport, entertainment, attractions), industry (accommodation services, food and beverage services, retail, transport, cultural, sports and recreational services) and sources of consumption (consumption of locals and tourists, domestic companies travel costs, collective expenditure of government entities on tourism

$1 \quad$ Modern Business School - Terazije 27, 11000 Belgrade, Serbia

2 "Čačak" Business School, Higher Education Institution for Applied Studies, Gradski park 2, 11080 Belgrade, Serbia; Modern Business School, Terazije 27, 11000 Belgrade, Serbia

3 "Čačak" Business School, Higher Education Institution for Applied Studies, Gradski park 2, 11080 Belgrade, Serbia 
and travel, export by visitors). The indirect benefits from tourism are: travel and tourism investment spending, government collective spending on tourism and travel. The secondary contribution that tourism has to the economic development of a country is primarily reflected in the employees' spending habits: catering, recreation, retail (Travel \& Tourism Economic Impact, 2017).

Tourism is a phenomenon that can be explained and defined through a multidisciplinary approach: tourism today is a blend of social, cultural, economic, and psychological factors. There are numerous definitions of tourism. World Tourism Organization defines tourism as 'activities of persons travelling to and staying in places outside their usual environment for not more than one consecutive year for leisure, business and other purposes not related to the exercise of an activity remunerated from within the place visited' (World Tourism Organization / UNWTO www.unwto.org).

International Association of Scientific Experts in Tourism (AIEST) formulated the following definition of tourism before the annual Congress held in Cardiff in 1981. The totality of the relationships and phenomenon arising from the travel and stay of strangers, providing that the stay does not imply the establishment of a permanent residence and is not connected with remunerative activities, whether for the purpose of holiday, business activities or studies (Vanhove, 2005).

The classification of tourism, or everything that can be classified, can be done in numerous ways, depending on the criterion. Health tourism today is one of the most promising branches of tourism.

\subsection{Health tourism as a separate part of tourism}

A fast and stressful way of life, a changing environment and uncertainty have made the issue of health and everything related to it become a dominant direction in the behaviour of a modern man, which also influences purchasing decisions and choosing the product. There are many reasons that have led to a change in people's behaviour and their interest in health programs. Key factors are: demographic trends, innovations in methods, equipment and ways of providing health services and professional skills of employees. When it comes to the demographic factors - most people have the fear of aging and illness. For this reason, persons' interest in health increases, and they turn to a healthy way of life to a particular extent and in a way that suits their lifestyle. Regarding this, a whole spectrum of different products, services and treatments has been developed, and the classic spa offer has been expanded with a whole range of different rehabilitation programs specialised for different professions, detox programmes or innovative dietary supplements, herbal medicine, etc.

The area of health tourism today is not based on classical medical treatments. The offer of health tourism institutions is fully based on the needs of potential users of their services. When it comes to Europe, and also all developed countries, the demographic structure of the population clearly shows that the population is getting older. Better standard of living, health and social care have made Europe's average life expectancy grow. For this population, health and a healthy lifestyle are ways of achieving healing or preventing the occurrence or spread of certain diseases, that are characteristic of this age. However, the situation in this field is changing as well. Although seniors - that is the elderly population - were the target market segments for health tourism, health tourism institutions are turning to new market segments with preventative or aesthetic motives. 


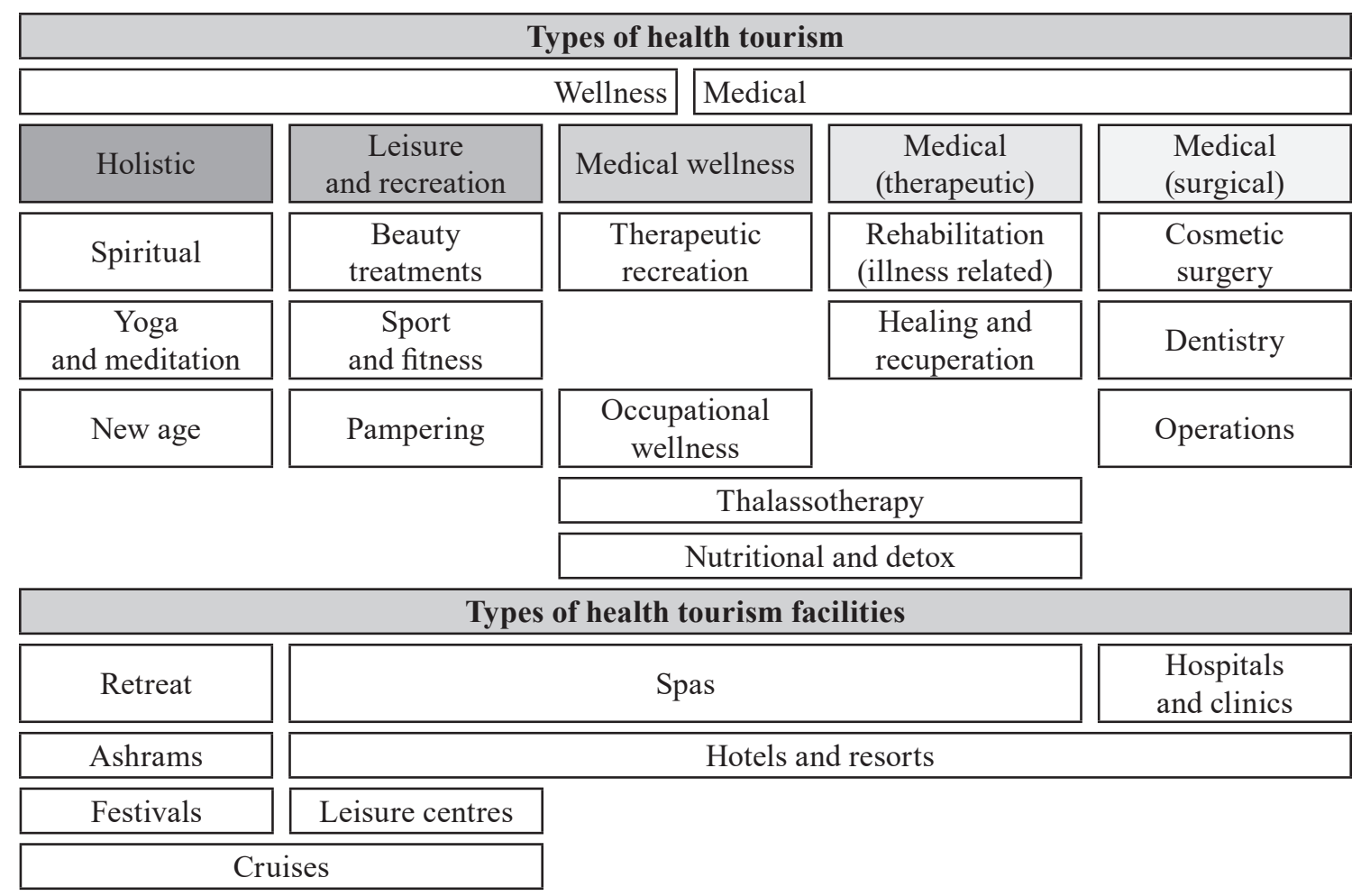

Figure 1. Spectrum of health tourism

Source: Smith, M. \& Puczkó, L. (2009).

Health and Wellness Tourism, Oxford: Butterworth-Heinemann pp.7

Another key factor when it comes to profiling health tourism are innovations. They are the basis for the development of modern health tourism and the attraction of different segments of users. Innovations, in this case, denote innovative technology and equipment in addition to adequate treatment and services it provides. Innovations have brought up a wide range of healthcare products and services that are not only used in health tourism institutions but can be applied in home conditions to a certain extent. Innovations in the field of technology and equipment have led to the development of certain types of health, wellness, medical tourism and institutions with no tradition in this field. This has led to more choices for potential users, but also to an increased competition among service providers. In this regard, health tourism institutions offer a package that includes a whole range of complementary services.

There is still some confusion in terminology. In practice, health tourism is often identified with medical or wellness tourism. The fact is that medical and wellness tourism represent a type of health tourism. Health tourism can be defined as an attempt of a tourist facility (e.g. hotels) or destination (e.g. Baden, Germany) to attract tourists by intentionally promoting their health services and facilities, in addition to their regular tourist facilities. These health services may include medical examinations by qualified doctors and nurses at a resort or hotel, special diets, acupuncture, trans-vital injections, vitamin complexes, special medical treatments for different diseases such as arthritis and herbal medication. (Goodrich \& Goodrich, 1991).

Professional competence of employees includes knowledge and skills that are oriented towards raising the quality of services and differentiating themselves from other providers of health services. In addition, the professional competence of employees enables a complete application of innovations in practice. 
Medical tourism exists when consumers decide to travel abroad due to treatment. This treatment can cover a whole range of medical services, but mostly includes dental care, cosmetic surgery, and certain types of surgery and infertility treatment (Lunt et al., 2011).

Wellness tourism can be defined as a sum of all relationships and phenomena arising from people's travel and stay, with the aim of preserving or promoting their health. They stay in a specialised hotel that provides appropriate expertise and individual care. They require a comprehensive package of services that includes: fitness, beauty care, healthy nutrition, relaxation, meditation and mental activity, education (Muller \& Kaufman, 2000).

It is difficult to distinguish medical from wellness tourism in some segments today.

\subsection{Valorisation of tourism potentials}

The most important criteria of tourist valorisation can be stated ${ }^{4}$ : the degree of attractiveness of tourist motives, the development of transport infrastructure, the degree of development of tourist capacities, the equipment on tourist sites and centres, geographic position, cultural and historical heritage, etc. The World Tourism Organization determined the most important criteria of valorisation of tourist potentials in the following ways:

\section{Internal factors}

A) The degree of use of tourist value (resource)

a) urbanisation

- assessment of the type, quality and level of the existing resource equipment;

b) infrastructure (urban and transport)

- the level of services offered (high, medium, low),

- supply level in relation to demand (high, medium, weak);

c) tourist equipment and services

- existing accommodation facilities (hotel and non-hotel)

- complementary tourist offer (restaurants, cafes, nightclubs, crafts, sports, travel agencies) and tourist services;

B) inherent characteristics of tourist values (resources)

a) natural resources, e.g. beaches (lake, river), quality and quantity are measured,

b) cultural resources (historical buildings and monuments)

- architectural value of the building, regardless of when it was built,

- permanent protection measures.

External factors (factors that determine business tourism)

A) accessibility of resources (traffic infrastructure),

B) proximity of emission centres,

C) specificity of tourist value (comparative analysis with other resources),

D) importance of resources - the impact on the image and market.

A large number of experts (Stanković, S, 1996) believes that the natural tourist values of Serbia are not properly valorised.

\footnotetext{
$4 \quad$ The views of several authors have been analysed: Nikolić, Jovičić Ž. Jovičić D. Stanković S. etc.

$5 \quad$ WTO - OMT, L' evalution des projets touristiques, Madrid, 1980.
} 


\section{SPA TOURISM IN SERBIA - PARTICULAR SPECIFICITIES}

The official definition of a spa is: spa is an area where exists and is used one or more natural healing factors, and which meets the requirements regarding the supplies and equipment for their use, in accordance with the provisions of this Law. Spa is a natural good of general interest, managed by the state, under conditions and in the manner defined by this Law (The Law on Spas, Official Gazette of RS, No. 80/92, 67/93). Spa tourism is a special and very widespread type of motive movement. Two basic characteristics of spa tourism are: 1. relatively long stay, which is explained both by recreational and therapeutic function of thermo-mineral sources; and 2. relatively even distribution of traffic by months, which is explained by the fact that healing waters can be used in medical and recreational purposes throughout the year, but the climate factor that affects the general mobility and spa visits cannot be neglected. If the emphasis in the development of spas is put on recreational and tourist function, the tourist traffic has a slightly more pronounced seasonal feature, which is especially seen in the spa located near the city centres (excursion tourism), but if a spa is well equipped with medical facilities, the healthcare function can be successfully developed all year round.

However, the effect of seasons can be considerably mitigated, not only by the development of a healthcare function, but also by enriching the supply with other amenities that would attract tourists' off-season, contributing to better business results and more even distribution of traffic during the year. Another feature of spa tourism is that spas are places with the most diverse structure of visitors - economic, social, age, etc. Also, there is a possibility to create a diverse tourist offer in spas, that is, the tourist offer is enriched with other types of tourism, so that various cultural, entertainment and sporting events, exhibitions and scientific-professional meetings are organised more often. It is clear that this fact imposes the need for a complex and well-thought-out approach to the tourist valorisation of the mentioned places.

The tables below show the spa potential of Serbia with distinctive specificities.

Table 1. Spa classification according to medical indications

\begin{tabular}{|c|l|l|}
\hline No. & Medical indications & Spa \\
\hline 1. & $\begin{array}{l}\text { Locomotor system / } \\
\text { Rheumatic diseases } \\
\text { Neurological diseases }\end{array}$ & $\begin{array}{l}\text { Banja Badanja, Brestovačka banja, Bujanovačka banja, Bukovička banja, } \\
\text { Vranjska banja, Vrnjačka banja, Banja Vrujci, Banja Vrdnik, Gamzigrad, } \\
\text { Atomska banja Gornja Trepča, Ivanjica, Jošanička banja, Banja Junaković, } \\
\text { Banja Kanjiža, Banja Koviljača, Lukovska banja, Mataruška banja, Novo- } \\
\text { pazarska banja, Ovčar banja, Palanački kiseljak, Prolom banja, Pribojska } \\
\text { banja, Ribarska banja, Banja Rusanda, Sokobanja, Stari Slankamen }\end{array}$ \\
\hline 2. & Gastrointestinal diseases & $\begin{array}{l}\text { Banja Badanja, Brestovačka banja, Bujanovačka banja, Bukovička banja, } \\
\text { Vrnjačka banja, Atomska banja Gornja Trepča, Prolom banja, Pribojska } \\
\text { banja }\end{array}$ \\
\hline 3. & Gynecological disorders & $\begin{array}{l}\text { Bujanovačka banja; Vranjska banja; Vrnjačka banja; Banja Vrujci; Gamzi- } \\
\text { grad spa; Jošanička banja; Banja Junaković; Banja Koviljača; Lukovska ban- } \\
\text { ja; Mataruška banja; Novopazarska banja; Sijarinska banja; Sokobanja; Stari } \\
\text { Slankamen }\end{array}$ \\
\hline 4. & Metabolic disorders & Bukovička banja; Vrnjačka banja; Sijarinska banja \\
\hline 5. & Respiratory system & Brestovačka banja; Bukovička banja; Ivanjica; Niška banja; Sijarinska banja. \\
\hline 6. & Skin diseases & $\begin{array}{l}\text { Brestovačka banja; Bujanovačka banja; Vranjska banja; Jošanička banja: } \\
\text { Banja Koviljača; Mataruška banja; Novopazarska banja; Ovčar banja; Pro- } \\
\text { lom banja; Pribojska banja, Banja Rusanda. }\end{array}$ \\
\hline
\end{tabular}




\begin{tabular}{|c|l|l|}
\hline 7. & $\begin{array}{l}\text { Cardiovascular and } \\
\text { cerebrovascular disease }\end{array}$ & $\begin{array}{l}\text { Vrnjačka banja; Banja Vrujci, Banja Vrdnik, Gamzigrad Spa; Atomska ban- } \\
\text { ja Gornja Trepča, Niška banja, Novopazarska banja, Banja Rusanda, Soko- } \\
\text { banja }\end{array}$ \\
\hline 8. & Urinary tract diseases & $\begin{array}{l}\text { Bukovička banja; Vrnjačka banja; Banja Vrujci; Prolom banja; Sijarinska } \\
\text { banja. }\end{array}$ \\
\hline 9. & Blood diseases & Banja Badanja; Ivanjica, Banja Rusanda. \\
\hline 10. & Oncology disorders & Ivanjica \\
\hline
\end{tabular}

Table 2. Therapeutic methods in spas

\begin{tabular}{|c|c|c|}
\hline No. & Spa & Treatment method \\
\hline 1. & Banja Badanja & $\begin{array}{l}\text { Water in Badanja is extremely healing and, during treatment, is used in two } \\
\text { ways - for drinking and bathing. The iron water is for drinking, while the } \\
\text { sulphur water is for bathing. }\end{array}$ \\
\hline 2. & Brestovačka banja & $\begin{array}{l}\text { The spa has five swimming pools and two tubs with thermo-mineral wa- } \\
\text { ter, and one hydrogalvan tub. Medical and physiotherapeutic services are: } \\
\text { bathing in swimming pools, baths, hydro massage, ultrasound, sonophore- } \\
\text { sis, electrophoresis, diadynamic currents, infrared magnetic field therapy, } \\
\text { bioptron light therapy, manual therapy and kinesiotherapy. }\end{array}$ \\
\hline 3. & Bujanovačka banja & $\begin{array}{l}\text { This is the only spa in our country that uses natural gas and carbon dioxide } \\
\text { for treatment. }\end{array}$ \\
\hline 4. & Bukovička banja & $\begin{array}{l}\text { The treatment takes place at the Special Hospital for rehabilitation "Bu- } \\
\text { kovačka banja". It consists of drinking mineral water, bathing in a closed } \\
\text { therapeutic pool or tub with underwater massage in thermo-mineral water, } \\
\text { applying clay, and other physical procedures: electro, mechano, magnet, ki- } \\
\text { nesis, laser. }\end{array}$ \\
\hline 5. & Vranjska banja & $\begin{array}{l}\text { Complete balneo-physical therapy includes electrotherapy, kinesiotherapy, } \\
\text { massage (manual and apparatus), swimming in therapeutic pools and tubs, } \\
\text { hydro massage and peloid treatment. }\end{array}$ \\
\hline 6. & Vrnjačka banja & $\begin{array}{l}\text { Special Hospital for Treatment and Rehabilitation "Merkur" is the most } \\
\text { modern health center for the diagnostics, prevention, treatment and rehabil- } \\
\text { itation of diseases of digestive system organs, diabetes and bone and joint } \\
\text { diseases. }\end{array}$ \\
\hline 7. & Banja Vrujci & $\begin{array}{l}\text { The rehabilitation center provides complete medical treatment: kinesiother- } \\
\text { apy, hydrotherapy, electrotherapy and mud therapy. }\end{array}$ \\
\hline 8. & Banja Vrdnik & $\begin{array}{l}\text { In the Special Rehabilitation Hospital "Termal" the treatment is carried out } \\
\text { with modern, top equipment for providing all methods of physical medicine } \\
\text { and rehabilitation (hydrotherapy, electrotherapy, kinesiotherapy, paraffin, } \\
\text { cryotherapy...) }\end{array}$ \\
\hline 9. & Gamzigrad spa & $\begin{array}{l}\text { The treatment takes place in a Special Hospital for Rehabilitation "Gamzi- } \\
\text { grad" with thermo-mineral water in galvanic baths, tubs, underwater mas- } \\
\text { sage. Electrotherapy, phototherapy, kinesiotherapy, thermotherapy, and ther- } \\
\text { apy with hyperbaric oxygenation are also applied. }\end{array}$ \\
\hline 10. & $\begin{array}{l}\text { Atomska banja } \\
\text { Gornja Trepča }\end{array}$ & $\begin{array}{l}\text { Physical treatment includes electrotherapy, laser therapy, magnetic therapy, } \\
\text { ultrasound and kinesiotherapy, manual massage, and balneotherapy includes } \\
\text { bathing in pools and tubs, pearl baths and hydro massage. }\end{array}$ \\
\hline 11. & Ivanjica & $\begin{array}{l}\text { It provides treatment and therapies for disease prevention, treatment, reha- } \\
\text { bilitation, recovery, recreation and rest. It provides internist and hematology } \\
\text { services, laboratory diagnostics, and physical medicine and rehabilitation. }\end{array}$ \\
\hline 12. & Jošanička banja & $\begin{array}{l}\text { Therapies are provided in "Novo kupatilo" with ten baths and one small } \\
\text { swimming pool, only therapeutic bathing is applied in treatment, i.e. hydro- } \\
\text { therapy, usually 2-3 times a day. }\end{array}$ \\
\hline 13. & Banja Junaković & $\begin{array}{l}\text { The treatment is provided under the supervision of a specialist team of doc- } \\
\text { tors and therapists, using hydrotherapy, electrotherapy, laser therapy, mag- } \\
\text { netic therapy, paraffin therapy, kinesiotherapy and work therapy. }\end{array}$ \\
\hline
\end{tabular}




\begin{tabular}{|c|c|c|}
\hline 14. & Banja Kanjiža & $\begin{array}{l}\text { The treatment is provided under the supervision of a team of specialized } \\
\text { physicians and therapists, using balneotherapy, peloid therapy, electrother- } \\
\text { apy, thermotherapy, mechano therapy, kinesiotherapy and manual massage. }\end{array}$ \\
\hline 15. & Banja Koviljača & $\begin{array}{l}\text { In addition to treatment, there are numerous diagnostic procedures and a } \\
\text { prevention program that is applied within the wellness center of Kovilje. } \\
\text { This institution also has a department for the rehabilitation of children, the } \\
\text { first of its kind in the country. }\end{array}$ \\
\hline 16. & Lukovska banja & $\begin{array}{l}\text { The treatment consists of hydrotherapy, manual massage, electrotherapy, } \\
\text { underwater massage and mud therapy. }\end{array}$ \\
\hline 17. & Mataruška banja & $\begin{array}{l}\text { The treatment takes place at the Natural Health Center "Mataruška and Bo- } \\
\text { gutovačka Banja" and the Special Hospital for Rehabilitation "Agens". }\end{array}$ \\
\hline 18. & Niška banja & $\begin{array}{l}\text { The treatment takes place at the Institute for Curing and Rehabilitation "Niš- } \\
\text { ka Banja", with modern equipment for non-invasive diagnostics, treatment } \\
\text { and rehabilitation of rheumatic and cardiovascular diseases and for operative } \\
\text { treatment in the field of orthopedic surgery. }\end{array}$ \\
\hline 19. & Novopazarska banja & $\begin{array}{l}\text { The treatment takes place at the Special Hospital for Progressive Muscular } \\
\text { and Neuromuscular Diseases Novi Pazar, which has modern physiotherapy } \\
\text { apparatus operated by professional personnel. }\end{array}$ \\
\hline 20. & Ovčar banja & $\begin{array}{l}\text { The treatment consists of bathing in thermo-mineral water and covering the } \\
\text { affected body parts. Therapies are conducted under the supervision of a spe- } \\
\text { cialist physician. During the treatment, balneological, physical and hydro- } \\
\text { therapy, massage and medication are used. }\end{array}$ \\
\hline 21. & Palanački kiseljak & $\begin{array}{l}\text { The treatment of patients is carried out at the General Hospital "Stefan Vi- } \\
\text { soki". The therapy includes drinking water, hydrotherapy, underwater and } \\
\text { manual massage, electro and phototherapy }\end{array}$ \\
\hline 22. & Prolom banja & $\begin{array}{l}\text { Treatment consist of drinking the healing Prolom water, hydrotherapy, mud } \\
\text { therapy, electrotherapy, magnetic, kinesiotherapy, manual massage and laser } \\
\text { therapy. }\end{array}$ \\
\hline 23. & Pribojska banja & $\begin{array}{l}\text { Treatment is carried out at the infirmary of the Rehabilitation Center "Pribo- } \\
\text { jska Banja", using modern methods of treatment and rehabilitation. Drinking } \\
\text { water is used for treating the functional diseases of digestive tract, bloating, } \\
\text { digestion problems. The treatment also includes hydro, kinesis and physical } \\
\text { therapy }\end{array}$ \\
\hline 24. & Ribarska banja & $\begin{array}{l}\text { The treatment takes place at the Special Rehabilitation Hospital "Ribarska } \\
\text { Banja", which is equipped with modern medical equipment. In addition to } \\
\text { kinesiotherapy, the treatment includes electro and work therapy, and swim- } \\
\text { ming in an indoor swimming pool with thermo-mineral water. }\end{array}$ \\
\hline 25. & Banja Rusanda & $\begin{array}{l}\text { Various diagnostic and therapeutic procedures are used in the rehabilitation } \\
\text { process, such as: kinesiotherapy, hydro-kinesis therapy, underwater mas- } \\
\text { sage, galvanic bath, four-cell baths, local and alternate baths with mineral } \\
\text { water, work therapy, electrotherapy, phototherapy, ultrasound therapy, paraf- } \\
\text { fin treatment, peloid therapy, speech therapy, acupuncture, neuropsychologi- } \\
\text { cal rehabilitation, laser and magnetic therapy. }\end{array}$ \\
\hline 26. & Selters banja & $\begin{array}{l}\text { The treatment is carried out in the medical center of the hotel "Selters" and } \\
\text { includes hydrotherapy, kinesiotherapy, electrotherapy, phototherapy, sono- } \\
\text { therapy, thermotherapy, work therapy, instrumental and manual massage, } \\
\text { and complete respiratory rehabilitation. }\end{array}$ \\
\hline 27. & Sijarinska banja & $\begin{array}{l}\text { The medical unit has the most modern equipment for hydrotherapy, mud } \\
\text { therapy, electrotherapy, kinesiotherapy, inhalation and hot baths in healing } \\
\text { water. }\end{array}$ \\
\hline 28. & Sokobanja & $\begin{array}{l}\text { In the Special Hospital "Sokobanja", the prevention, diagnostics and treat- } \\
\text { ment of respiratory, cardiovascular, locomotor, rheumatic and neurological } \\
\text { diseases are carried out, as well as the medical rehabilitation. }\end{array}$ \\
\hline 29. & Stari Slankamen & $\begin{array}{l}\text { The treatment takes place at the Special Hospital for Neurological Diseases } \\
\text { and Posttraumatic Conditions "Dr Borivoje Gnjatić", which specializes in } \\
\text { the treatment of hemiplegia. }\end{array}$ \\
\hline
\end{tabular}


Vrnjačka Banja has a long tradition as a health resort. Between the 2nd and 4th century AD, the Romans built their health and recuperation resort of AQUAE ORCINAE on Vrnjački thermo-mineral water spring. The modern spa has had a 150-year-long tradition. Before the Second World War it used to be a fashionable centre visited by kings, rulers, and numerous renowned people. According to the quality and the curative quality of the spa, Vrnjačka Banja was compared to Baden Baden and Karlovy Vary. Officially, the first season in the spa was opened in 1868.

Sokobanja spa is located in the central part of eastern Serbia, $234 \mathrm{~km}$ away from Belgrade, and $60 \mathrm{~km}$ from Niš. It is nestled in the valley between Ozren and Rtanj mountains. The spa existed in the Roman time as well, which is testified by numerous Roman graves and objects as well as by the remains of the Soko-grad fortress. On the Roman foundations, the Turks built a hamam bath in the 15th century, which is the oldest building for curing people in Sokobanja spa. Sokobanja spa is specific for its climatic conditions, its unique flora and fauna and rich cultural-historical heritage. In 1992 the spa became the first ecological municipality in Serbia.

Banja Koviljača was spontaneously established in the area covered with marshes around a spring of healing water. The first written record of Koviljača dates back to 1533. As in those times wealthy Turks visited the spa with their families, they built the first female hamam baths there in 1720. Banja Koviljača became a spa resort during the rule of Serbian King Peter I Karadjordjević, who built a modern sulphur bath in 1908, which has remained in use even today.

Prolom Banja is perched on the eastern slope of Radan mountain, at 550 to $668 \mathrm{~m}$ above sea level. It is surrounded by pristine nature of exceptional beauty. In this region the remains of prehistoric spas from the third millennium BC have been discovered. Therefore, some argue that this may be the oldest spa in the world. Following this discovery in 1928 the modern exploitation of mineral water started.

Lukovska banja is a spa that has only recently started to be exploited in modern sense. However, curative springs were used by the Romans as shown by the pipes and ancient ruins found on this site. The settlement also existed during the Middle Ages, as evidenced by old mines, churches and medieval fortifications.

Bukovička spa has celebrated its 200th anniversary as the beneficial effect of this mineral water has been known for a long time. Officially, the spa started operating in 1811 while the spa water was analysed first in 1835. The members of Serbian royal dynasties Obrenović and Karađorđević as well as their court retinue were treated here or visited the spa for rest. The spa was developed following the model of elite European spas.

In the time of Ancient Rome, Roman legionaries found a cure for their diseases on these springs. The first record of the natural healing quality of the water dates back to 1525 . The official natural health resort was established in the late 19th century, thanks to a distinguished merchant from the village of Gornja Trepča, who had built the bathing establishment. It was ten years later that the administration of the Vujan Monastery added bathrooms to it and built a 10-room building and an inn. The curative water was analysed for the first time in 1904, and the spa officially started operating in 1955.

The story about Ribarska banja says that people have always been visiting these healing springs to treat their diseases and recover or simply to enjoy the beauty of the landscape. According 
to the written sources in Roman times this place used to be a true health resort. In the Middle Ages, during the rule of the Ottoman Turks, a hamam bath was built on this spot. Later, the springs were frequently visited by many Serbian rulers.

At first Vrdnik was a mine. Thermal water gushed forth into the pits of the mine in 1931, but it was not until the 1970s that the spa became a health resort with accommodation capacities and recreational facilities.

The tradition of spa in Banja Kanjiža is 900 years long. However, the first health resort was built at the beginning of the 20th century by Herman Grinfeld, a renowned industrialist. The spa was officially established in 1913.

Having in mind the seasonality in tourism, there are three groups of spas:

- group I is made up of spas which make most of the turnover in the summer. These are the spas with the smallest capacities, incompatible offer and the smallest tourist traffic, which are characterized by a greater distance from the major tourist dispersions of our country. This group of spa participates with only 5-6\% in the total number of overnight stays in spas in Serbia. These include: Bogutovačka, Brestovačka and Lukovska spa;

- group II are spas that have a colder and longer winter season, since over $20 \%$ of their annual turnover is realized in the period September-April. This includes five of our most popular and most developed spas, which absorb over $2 / 3$ of the total tourist traffic in the Serbian spas - Vrnjačka Banja, Sokobanja, Niška Banja, Mataruška Banja and Banja Koviljača;

- group III of spas absorb around 30\% of the spa tourist traffic and they are characterized by a variable and uneven distribution of tourist traffic by months. Mataruška Banja and Gornja Trepča are the most important among these spas, due to their solid construction and good position in relation to communication directions.

The activities and traffic in more than 30 spas are being monitored today in the Republic of Serbia. Some people believe that the number of spas in the Republic of Serbia is greater, but due to the unregulated land documentation and the registry of thermal waters, everything remains at the level of "wild" spas or health resorts (Anufrijev A., Dašić G. 2018). Below is the map of the spas of Serbia.

Tabayashi (2010) analyzed the tourism resources on the alluvial fan and its surrounding areas are examined by dividing them into natural and cultural tourism resources, and tourism facilities, just as they are analyzed in the Joetstu region. Natural tourism resource is a gorge formed by the Kurobe River, which originates in Mt. Washibadake in the northern Alps, and the deepest section is $1500 \mathrm{~m}$. The Kurobe Gorge Rilway runs 20,1 km from Unazuki to Keyakidaira, and one can see a magnificent view of the gorge from the train window. Approximately, 130 ha of cedar forests used to occupy the area of spring-fed water on the Kurobe alluvial fan. However, it has been reclaimed into rice paddies by the field improvement project since the 1960s, and only one cedar forest of 2,7 ha remains at present. The sand of Ishidahama bathing beach is protected by the breakwater in Ishida fishing harbor and Sakai beaches in Asahi town is a rare gravel beach in Japan called jade beach since raw jade stones can be found there. It is also famous as bathing beach. Asahi town is starting point for a climb to Mt. Asahidake (2418m) and Mt. Hakubadake (2932m) in the northern Alps. 
For example, our neighbors Hungarians are sea that does not have replaced the spas whose qualities many tourists mostly. Hungary is every year emphasizes its catering, hospitality, culinary and spa tradition. Hungary is in the region excelled in spa tourism. Its area is rich in mineral and thermal waters, which are suitable for the development of spa tourism in the segment of treatment, rehabilitation, or in the segment of rest and relaxation.

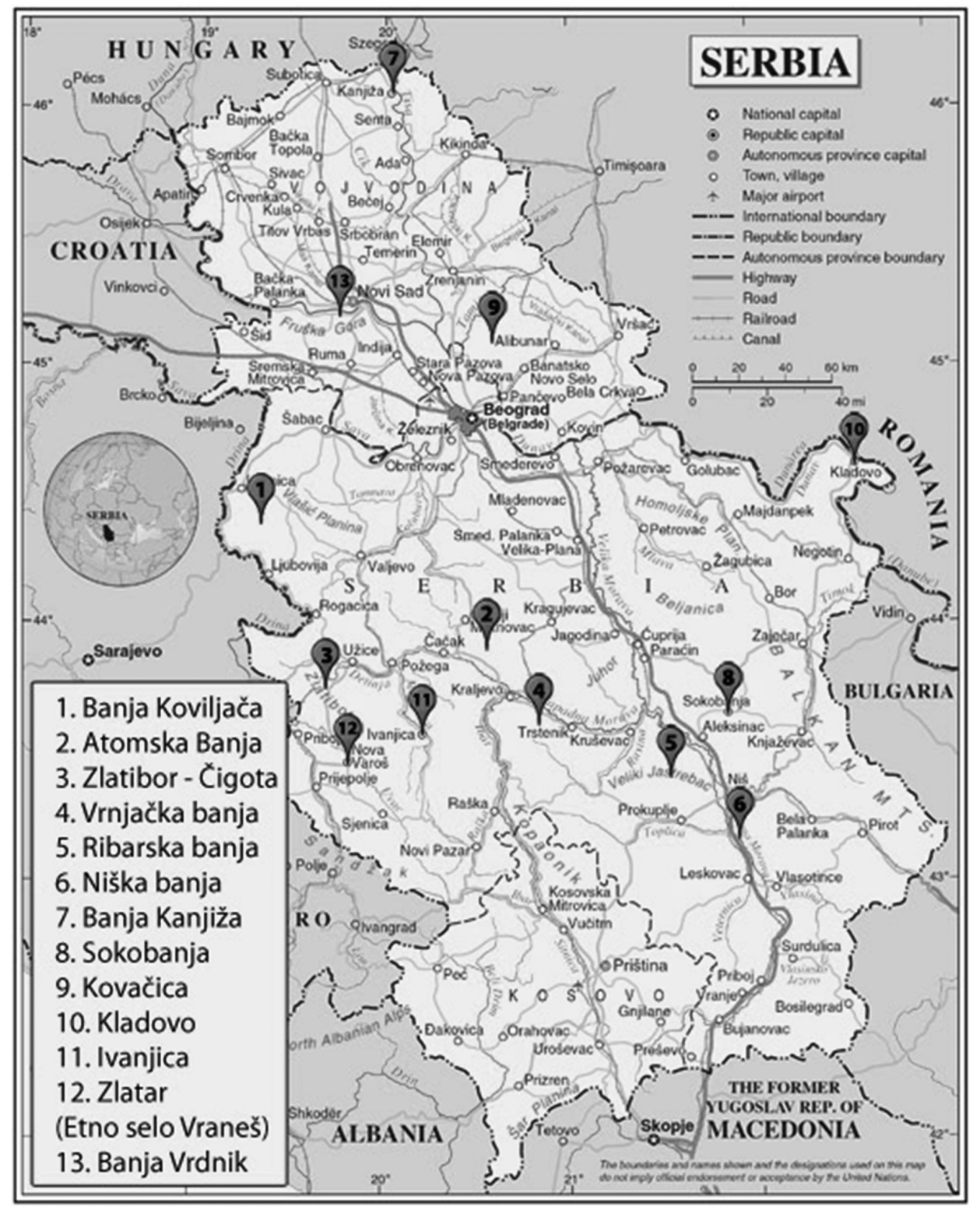

Figure 2. Map of Serbian spas

Comparing folder spas in Serbia, we can see that they are located in areas with rich natural environment, clean air, wind power, along rivers or mountain ranges. Some are in the vicinity of large cities (Koviljača spa, Vrnjačka spa, Seltres spa, Kanjiža, Soko spa, Niska spa), and some are in rural areas below mountain ranges in other rich natural habitats of flora and fauna (Prolom spa, Vrujci spa, Mataruska spa, Atomska spa, etc). Options for the development of rural tourism with spas located in rural areas are great but underutilized at the moment. This issue is of particular importance, on which to develop a detailed strategy for the future. In Addition, it is also possible rural and healthy agriculture include in part of rural spa tourism, which will significantly increase the importance of such centres. 


\subsection{Weaknesses and limitations}

The basic problems, which hinder the expansion of spa tourism in Serbia, can be classified in the following way:

- poor tourist offers and the lack of strategic approach to spa tourism planning;

- lack of stable financial sources;

- domination of domestic tourists;

- bad legal acts, which, despite their shortcomings, are poorly applied;

- poor tourist animation of potential clients;

- lack of market research;

- obsolescence of medical equipment;

- unsatisfactory general and tourist infrastructure;

- failure to use the concept of sustainable development and the immoderation in tourism construction have led to a number of negative effects in the previous period, thus threatening the natural healing factors and the overall environment of spas;

- a set of offers that are inaccessible to low-income populations, and

- a scarce number of spas for children rehabilitation.

Identifying weaknesses require additional work in order to create better conditions for treatment and spa. For certain categories of these two services need to connect, so in the future we need to work on the merger of various treatments and spa services, so the effects of health and pleasure are fully met. Also, it is important to note that the spa tourism in Serbia is quite expensive and is therefore unattainable for the majority of the population. In this regard, Serbia would be able to follow the tendency of Hungary, which is the price of their spa centres and spas significantly adjusted extensive population. In terms of culture about visit spa centres is a need to talk further, especially because of the long tradition that Serbia has in spa centres.

\section{CONCLUSION}

Since tourism is the backbone of economic development, activities in this segment must be continuous. Spa tourism as a product in Serbia is aimed at preserving natural thermo-mineral sources and traditional medicine. Services have been modernised, content and services have been expanded, infrastructure has been improved, but facilities, services, expertise and relaxing packages are demands that are constantly growing. These spa offer demands must constantly be monitored and met.

Spa tourism is an old, yet authentic form of tourism which is suitable for a large number of tourists. It is based on various methods of use of natural curative resources, mostly thermo-mineral waters and a number of skills and practices used to treat both body and soul. A wide range of wellness treatments make use of long-known healing properties of thermo-mineral waters, peloid mud, gasses and climate, ensuring relaxation and relief from stress or treatment of various diseases. Because of natural water, geographic potential and health potential, the spa and health tourism are very important for Serbia. 


\section{REFERENCES}

Anufrijev, A., Dašić, G. (2018) Challenges of spa tourism in the Republic of Serbia for the rehabilitation of Children with motor skills problems - Tourism in function of the development of the Republic of Serbia, Thematic Proceedings vol. II (pp. 714-731)

Goodrich, J. N., \& Goodrich, G. E. (1991). Health-care tourism. In S. Medlik (Ed.), Managing tourism Oxford: Butterworth-Heinemann. pp. 107 (pp. 107_114).

(1989). UN Convention on the Rights of a Child

Lunt, N., Smith, R., Exworthy M., Green, S. T., Horsfall, D. and Mannion, R. (2011) Medical Tourism: Treatments, Markets and Health System Implications: A scoping review, OECD - Directorate for Employment, Labour and Social Affairs, Paris.

Muller, H., Kaufman, E. L. (2000). Wellness Tourism, Journal of Vacation Marketing, 7(1), pp 5-17. Smith, M. \& Puczkó, L. (2009). Health and Wellness Tourism, Oxford: Butterworth-Heinemann Stanković, S., Priroda kao turistička vrednost Jugoslavije, Zbornik radova „Turistički potencijali Jugoslavije, Novi Sad, 15-16. November, 1996.

Tabayashi, A. (2010). Regional Development owing to the Commodification of Rural Spaces in Japan, owing to the Commodification of Rural Spaces in Japan, Geographical Review of Japan Series B 82(2): pp. 103-125

The Law on Spas, Official Gazette of RS, No. 80/92, 67/93

Travel \& Tourism Economic Impact 2017 (2017). World Travel \& Tourism Council

World Tourism Organization (UNWTO) - http://www2.unwto.org/en

Vanhove, N. (2005). The Economics of Tourism Destinations, Elsevier Butterworth-Heinemann, Oxford. 